\title{
EGFR NP_005219.2:p.D770_N771insMATP
}

National Cancer Institute

\section{Source}

National Cancer Institute. EGFR NP 005219.2:p.D770 N771insMATP. NCI Thesaurus. Code C98652.

An insertion of the amino acid sequence methionine-alanine-threonine-proline between the aspartic acid at position 770 and the asparagine at position 771 of the epidermal growth factor receptor protein. 